\title{
Historein
}

Vol 8 (2008)

Performing Emotions: Historical and Anthropological Sites of Affect

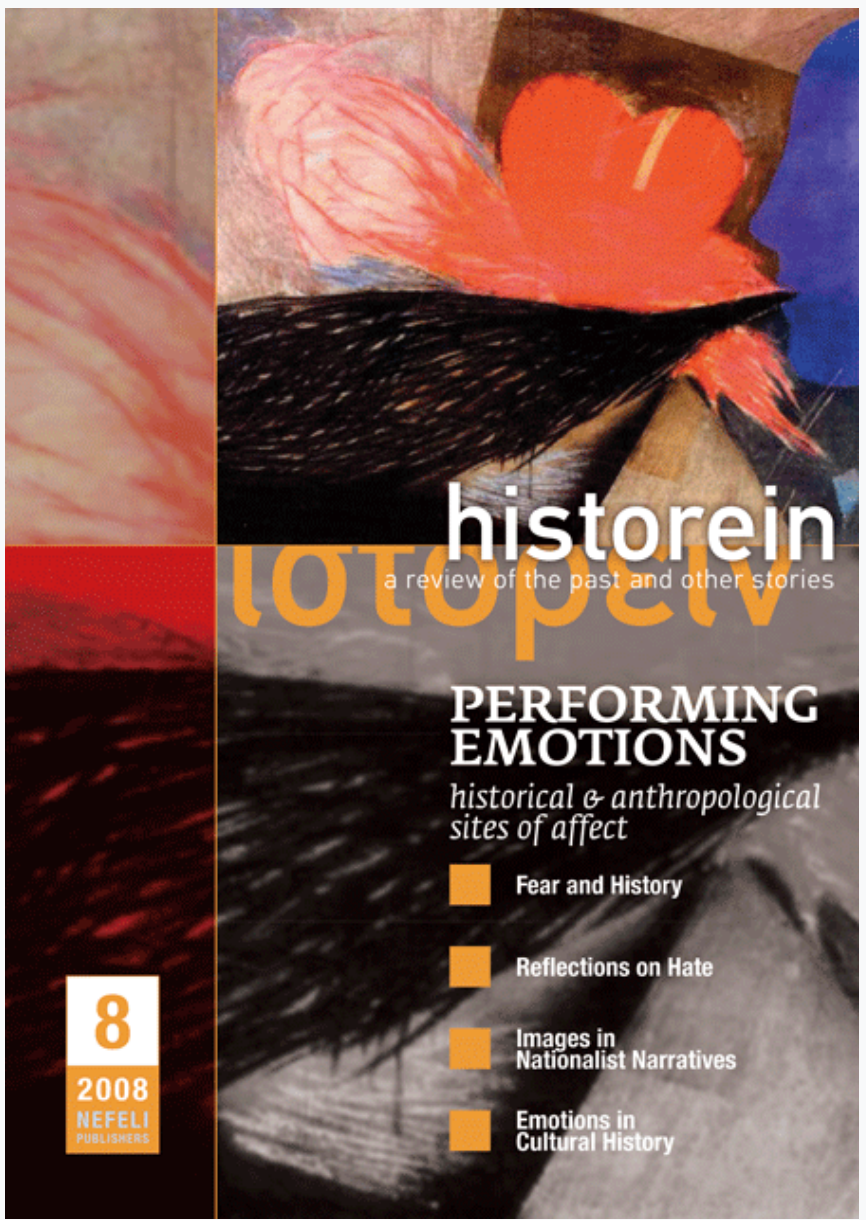

Of Euro-Symbols and Euro-Sentiments: The Case of Town and School Twinning

Eleni Papagaroufali

doi: $10.12681 /$ historein.39

Copyright @ 2012, Eleni Papagaroufali

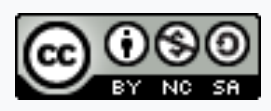

This work is licensed under a Creative Commons Attribution-NonCommercialShareAlike 4.0.

To cite this article:

Papagaroufali, E. (2009). Of Euro-Symbols and Euro-Sentiments: The Case of Town and School Twinning. Historein, 8 , 72-82. https://doi.org/10.12681/historein.39 


\section{Of Euro-Symbols and Euro-Sentiments: The Case of Town} and School Twinning
Along with the European Union's economic and juridical agenda, a whole series of so-called 'cultural' policies have been implemented,' including the European Union emblem and flag which appears nowadays on all public buildings and offices; the European anthem, the "Ode to Joy", taken from Beethoven's Ninth Symphony as best capturing the European idea; the "European city of culture"; EU-sponsored sporting, writing and other competitions and awards; the establishment of the "Women of Europe" awards; the designation of "Europe Day" on May 9, the date of the Schumann Declaration which led to the creation of the European Coal and Steel Community; educational exchange programs such as Erasmus, Socrates, and Leonardo; and town twinning - to name but a few! ${ }^{2}$ The goal of such topdown strategies is to promote Europeans' consciousness of their 'common heritage and identity', and give Europe a 'soul' - a requirement recognised in Jean Monnet's declaration that "We are not forming coalitions between States but union among peoples;" ${ }^{3}$ in Jacques Delors' warnings that people do not fall in love with a market, but need something else; ${ }^{4}$ and finally in policymakers' assertions that European citizens feel "moved on hearing the Ode to Joy" or "enjoy following the European sign in airport arrival halls, and passing through simply by showing the uniform passport adopted in 1985".

Most social and political analysts of European politics consider these 'Euro measures' to be 'merely symbolic', meaning of minor political significance (when compared to the 'real' economic and legal restrictions on the movement of goods, funds, information and labour) and of no sentimental value for the Europeans. As 
a result of this stance, there is little or no research on the small-scale civilities and the rituals or ceremonies involved in these symbolic measures. Also, instead of focusing on the "considerable effects" of such policies, ${ }^{6}$ or on the "latent legitimacy" the EU enjoys through processes of popular attachment to it, occurring at the level of everyday life in a myriad of ways (consumerism included), ${ }^{7}$ most analysts point to the deficiencies or contradictions of the European Commission, ${ }^{8}$ as well as to its disavowal of the affective, passionate and libidinal/joyful dimension of the identification process. ${ }^{9}$ As a consequence, the Eurobarometer and similar large-scale surveys are the only sources available to show that European citizens feel either "little" or "not at all" European, or that they consider these symbolic practices of secondary importance or as purely decorative. ${ }^{10}$

\section{The European Union's politics of emotion}

Nevertheless, a closer analysis of concrete examples reveals that EU policymakers are just as aware as anthropologists that what is stereotypically constructed as 'merely symbolic' does not simply reflect but rather actively creates political realities due to its capacity to draw the attention of the public, thereby engaging people in emotional states of various kinds. Therefore, the Commission's attempts to mobilise popular support by creating public symbols for the EU should be seen as part of a long-term, more or less explicit, "politics of emotion","1 or of what a French colonialist once called éducation du coeur..$^{12}$ In this case, emotions or sentiments and sensations are understood not as biological endowments but as cultural idioms of belonging that can be fostered through tropes of familial ties (for example, the "European Family", the "European House", "Twinning"), and acquired through multisensory stimulation and training (for example, festive ceremonies and joyful exchanges between "twinned" town dwellers and school pupils). In fact, drawing on the assumption that the Union's member states share a common fate - meaning that the European integration project is inevitable - Commission officials consider these practices the perfect means to construct Europeanness as an affective site of affiliation and identification; or, to make the 'peoples of Europe' both to 'learn to love' European matters and be ready to defend them as 'theirs'. It is worth remembering the intensive campaigns launched by the Commission during the late 1990s in order to convince European citizens to "learn to love" the merits of their new common currency. ${ }^{13}$ Nowadays, the extent to which this readiness to feel intimate with the imposed Other, and to defend it as 'one's own', may be measured by instances like the following: a 15-year Greek girl whose school twinned with a Turkish school in 2003, complained intensely to me that the Turkish shop owners would not accept "euros" from their Greek customers. To my remark that "Turkey has its own national currency" and that "it is not yet an EU member", the schoolgirl replied scornfully that "the longer the Turks don't accept the euro, the farther off their integration into the EU will be!"14

The generous financial support for all kinds of sentimental training in matters European concerns the Union's 'old' and 'new' members and 'candidate' and 'potential candidate' states - the last two categories include Turkey, Serbia, Albania and FYROM among others. Consequently, the massive promotion of 'merely symbolic' policies prescribes not only who should be intimate with whom and in what way, but also who deserves this intimacy, hence its legitimate recognition as a member of the European Family. The Commission's extensive "investment" in the normative "distribution of [familial] affections" among its members, ${ }^{15}$ as well as its enormous interest in 
creating multiple microsites of intimate space - where the obligatory becomes naturalised and pleasurable, thus fully enmeshed in its technologies of governmentality - is best exemplified by the institution of twinning. Twinning between European cities, towns, schools, and all sorts of local bodies aims at making the so-called "peoples of Europe" rise above conflicts inherited from the past while acknowledging their "cultural differences". It is held that through this "local-level" apprenticeship, European locals of the north, south and east will learn how to "feel like citizens of Europe" and will actively contribute to the formation of a "new European identity". ${ }^{16}$ Thus, twinning forms a framework for national histories to get recast in a transnational, affectively appealing, common space of European citizenship.

\section{Town twinning and the European family}

The desired kind of relations between the European family members is articulated through the kin term 'brothers' and, more exactly, 'twins' - since most member states have adopted the term "twinning" in their own language. ${ }^{17}$ The banality of the term (brotherhood(s), brotherlike alliances, etc.) and its age-old performative reiteration for the establishment of connective narratives and reconciliation between actual and potential enemies ${ }^{18}$ present us with interesting points. On the one hand, they remind us that "sovereignty continues to draw life from the family", ${ }^{19}$ namely the ideal of disinterested and connective, conjugal, parental, brotherly, kin love. "Regulating the intimate and 'policing the family"' between colonisers and the colonised have always been the primary reformist practices by which Western and Eastern (neo-)colonial forms of governance were more or less secured and worked out. ${ }^{20}$ By the same token, the language of familial, enduring affection and the creation of fraternal bonds have been defining features of national states. ${ }^{21} \mathrm{On}$ the other hand, the imperative to reiterate kin metaphors reaffirms that expansive projects such as European integration can never be fully complete, and shows the planners' (at least partial) awareness of their projects' vulnerability. For instance, town-twinning aims at bringing together 'peoples' who are not merely 'culturally different' but have been, or still feel, inimical to each other - for example, the French, the Polish and the Germans, the Israelis and the Palestinians, the Greeks and the Turks, etc. In such cases, twinners hope for "the [mutual] acknowledgment rather than the solution of the pain" suffered in the past or nowadays. ${ }^{22}$ Yet, the extent to which old wounds may have been "forgiven" but not "forgotten", ${ }^{23}$ and hence whether the pain will be mutually acknowledged, are difficult questions that might lead to unhappy answers.

All these inherent difficulties notwithstanding, the term 'twinning', combined with the naturalised terms 'local(s)' and 'people(s)', renders the image of a large 'European' family intelligible and intimate to European audiences - to paraphrase Cris Shore, the "European family" campaign (like the "European citizenship" one) "makes the EU more visible to its newly constituted subjects so that they see themselves reflected in its largess". ${ }^{24}$ Despite its banality, or thanks to it, the constant reiteration of the 'family' by Union officials denotes the latter's performative force owed to its supposedly "fundamental" traits: "the self-governing couplet of 'I-Thou", which becomes "One" through the "intimate event [of love]"; and "the unity of 'We [-as-One]", this metaphysical, yet wellrooted and house-kept "idyllic bond" that "unfolds out of this couplet, followed in turn by various levels of social organisation - say, our 'family', 'nation', 'race', 'culture', 'religion'”. ${ }^{25}$ That Union 
officials are not satisfied with the idea of mere 'brotherhoods' but opt for 'multiple twinnings' between local bodies denotes their expectation that EU partners interact at the 'local', meaning 'small-scale', 'family' level, so that they learn to feel not merely as 'brothers' but if possible as "twins" - the master metaphor of the Same. Given their awareness that the European family is still under construction, they finance what Hannah Arendt would call a "gigantic [supra-] nationwide administration of housekeeping", ${ }^{26}$ or what Elizabeth Povinelli aptly calls a (neo-) liberal form of "oikopolitics", ${ }^{27}$ that is, practices of pedagogical-disciplinary care that are based at the values of the global market but are applied on the "intimate" level. Central to the oikopolitical nature of the nearly 30,000 twinning links is the notion of love in its symbolic, hence normative, version: it is performed as a Foucaultian regulatory ideal, namely as a set of regulatory practices aiming at administering the forms of intimacy considered 'appropriate' among those who wish to acquire and maintain the identity of the European family 'member'. Thus, it is not only 'joy' that should be felt in a certain European (Beethoven "Ode to Joy") way; mutual 'love' should also have a certain expression, that of 'we-as-one' in its brotherly or twinned version. As a consequence, the main twinning activities (exchange of visits and gifts, dancing and singing, planning and implementing agro-tourist partnerships, hosting partners' children during the summer, etc.) presuppose the notion of mutual rights and duties - as if the old, new, and accession members were family. Twinned European citizens are financed to visit their partners' places in order to get to know and acknowledge each other's different cultures and local histories rather than to behave as tourists, i.e., just to disinterestedly observe the Other and leave. In short, twinning could be seen as an affective cultural idiom of citizenship, one that seeks to administer internal borders and their historical connections to national identities in a unifying Europe.

As it will be shown below, twinning is an inherently contradictory institution (due to its normativeregulatory nature) which affirms and simultaneously disrupts relations at the local and translocal level. Nevertheless, it is widely welcomed by 'local peoples' throughout the EU, including Greece. The Commission's financial support is certainly quite appealing, but people's appreciation for certain partnerships plays an equally important role in twinning. So far, twinners have been totally free to choose their partners according to their own criteria. For example, Greek municipalities have twinned with southern Italian towns that were once ancient Greek colonies; they have also twinned with Bulgarian, Romanian and Serbian towns with the aim of establishing economic partnerships related to tourism; and with German, French and Belgian cities where Greeks used to live as immigrants; as well as with Turkish municipalities where Greeks lived since ancient times until they were expelled at the end of the Greco-Turkish War in the 1920s.

This freedom to choose one's own criteria not only underscores the Commission's purpose to make EU-citizenship affectively appealing but fits perfectly with the central value professed by the ideal of love or intimacy in its (neo)liberal version: to feel intimate presupposes the freedom from social constraints such as kinship, local tradition, national history, etc. ${ }^{28}$ Thus, despite the fact that twinning has substituted the (upsetting) notion of 'freedom' with the (levelling) idea of 'love', it nonetheless provides hundreds of thousands of total strangers with the freedom (and the means) to consent to multiple synergies. In all these forms of "contractual freedom", ${ }^{29}$ the metaphysical 'We-as-One' is supposed to consist of self-sovereign individuals of any age and gender who agree upon developing mutual relations of affectivity and intimacy, out of their own volition rather than out of obligato- 
ry conventions such as social status by birth, etc. Moreover, the recreational character of twinning activities (including the economic ones) provides twins with pleasurable, even idyllic and liberating, experiences: Greek pupils who twin with other European schoolboys and -girls flirt with their new friends and keep up contact through email and text messages in the hope of meeting again; adult men and women who previously had never travelled abroad may find themselves enjoying new experiences such as travelling by airplane or reliving a second honeymoon!

The expectation (raised both from 'above' and 'below') that twinning bonds should - by definition overcome not only conflicts inherited from the past but also be more than mere coalitions and "partnerships" between states, ${ }^{30}$ obscures whatever disagreements, rivalries and disloyalties are pending in the history of a community, inside it and in relation to potential twin brothers and sisters. Nevertheless, sooner or later, the performative distribution of those who are allowed to 'love' the Other symbolically (as if they were family) brings to the fore the contradictions (and exclusions) inhabiting this regulatory ideal: while some people exclude themselves from twinning out of disagreement with the institution itself or with the specific partnership-to-be, others (the majority) are excluded for not fulfilling the criteria of the specific twinning case. The potential or actual return of the excluded in order to sabotage and even determine the outcome of twinning processes reveals the limits of normative intimacy, namely, its constitutive dependence on both those who do not acknowledge it and those who are not acknowledged by it. Consequently, the festive character of twinning fails to conceal such latent threats, or to escape the disputes that (re)surface on the occasion of twinning, both among fellow citizens who pretend to live their everyday lives 'in peace' (like a family) and between citizens of member states with a peaceful or a hostile past or present. The following examples of twinning between Greeks and their others illustrate these remarks.

\section{The Greek Eurothermometer}

When the residents of the southeastern Attican municipality of Palaia Focea ${ }^{31}$ (Greek: Пa $\lambda$ alá Фúkaı, meaning Old Focea) decided to twin with their ancient Focean ancestors' colonies established in Italy (Ascea Velia), Spain (Ampuria) and France (Marseille) in $600 \mathrm{BC}$, they thought it absolutely "natural" to include in their visit exchanges only "authentic" Foceans, namely those who had come to this area of Greece from Asia Minor in the early 1930s as political refugees. ${ }^{32}$ Some of the excluded residents (i.e., Vlachs and Sarakatsans living in the area prior to the arrival of the Focean refugees, Cypriots inhabiting the place since the Turkish invasion of Cyprus, Greek workers originating from all over Greece, foreign immigrants) expressed indifference towards twinning, whereas the majority felt annoyed by the "authentic" Foceans' "arrogance" and accused them for "eating European Union money". Moreover, the fact that "Albanian children" had to be included in the group of school pupils on the visit to Italy fuelled a lot of quarrels which only abated at the last moment through the intervention of a fervent supporter of twinning. When some Foceans became interested in twinning with the place of origin of their ancestors in Turkey, modern-day Foça, the municipality divided into a minority in support and a majority in opposition. Most Greeks could not even think of twinning with the "enemy", whereas Greek Cypriots became furious with the "treachery" of the Foceans. Needless to say, "foreigners" (Albanians, Kurds, Egyptians) were never asked about this issue. 
On their arrival to Turkish Foça (1991), Greek Foceans met with many people who "acknowledged", hence became "witnesses" of, ${ }^{33}$ their grandparents' and parents' painful past: with old women and men who "knew" exactly where the Foceans' grandparents lived and worked, and who took guests "by the hand" to show them these places; with Turkish newcomers who now lived in the parental houses of the Foceans and who still kept the legitimate owners' keys by the door; with grandchildren of Muslims who lived in Greece before 1922 (before being "exchanged" for Christians living in Turkey) and who still spoke Greek. All of them reassured the Focean visitors that their expelled forefathers used to live "like brothers" with Turkish Foceans. Nevertheless, when these Turks first visited Palaia Focea in Greece (1993), the opponents distributed hundreds of flyers demanding "Turks out of Focea". In the following years, many more Foceans (including many former opponents) visited their "lost fatherland" and met, danced, and sung with local residents. Greek Foceans' involvement with "the Turks" filled them with positive sentiments: "Although poor, Turks are warmer and more hospitable than us and more so than the Italians and Spanish." However, during their second visit to Palaia Focea (2003), the Turks had to face many unfortunate incidents (for example, when some primary schoolchildren booed the Turkish pupils while they were singing the Turkish national anthem) which were abated at the last moment by twinning supporters. The festive ceremonies continued 'normally' thanks to the assurances of most participants that nothing wrong was going on. That the twinning between Greek, Italian and Spanish Foceans took only three to four years to be fully and 'officially' complete, while the one with the Turkish Foceans took ten whole years, is not coincidental. Most of the Old Foceans of Greek and Cypriot origin continue to criticise this "sacrilegious act" and "feel deeply disappointed and sad about it". Even those Foceans who visit Turkey quite often keep questioning "the sincerity of Turks' [brotherly] feelings" and emphasise the blind spots of this Greek-Turkish twinship: “Turks present 'our' ancient marbles as 'theirs'”; in the tourist flyers, Turkish Foceans attribute their municipality's name, Foça, to the existence of 'focies' (meaning seals in Greek) rather than to their ancient ancestors, the Focean founding fathers. And although the very same complainants laugh at "the theory that we [Greek and Turkish Foceans] come from the same [Focean] origins", they nonetheless declare their mistrust of the Turks: "They misrepresent us [Greeks/Greek Foceans]! How is it possible then to trust them?" No matter how "official" such Greek-Turkish twinships may be considered, it is obvious that the limits of normative intimacy are on the brink of resurfacing at any time; as a consequence, the expected 'completion' of twinning can be easily deconstructed and thus deferred to the midst of the European 'common future'.

Paradoxically, this deconstruction and/or deferral, which does not concern the 'enemies' exclusively nor is it always so explicit, is most often performed through the reiteration of a commonsensical discourse about the supposed "warmness" and "coldness" of the sentiments felt by the twins-tobe during their preparatory exchange of visits - perfect proof that 'merely symbolic' euro-policies, such as twinning, are external neither to the 'non-symbolic' or the 'real' nor to the 'sentimental'. For instance, Greek nationalist biases seem to soften (or come under strain) depending on the degree of warmness shown by their hosts. Thus, according to the Greek Eurothermometer, "the Spanish" (in particular the Catalans and the Andalusians), "the [southern] Italians", "the Turks" and the "Balkan peoples" emit the highest temperatures. Conversely, the "[western and northern] Europeans" are classified as "gentle" but "cold", meaning "non-hospitable", "cheap" and "snobby": "the Europeans" tend to "observe" their Greek visitors rather than "to get to know them". 
Nevertheless, warm sentiments do not necessarily guarantee the inclusion of the Other in oneself, nor the acknowledgment of the Other as 'equal' with oneself. The Greek high-school teachers and students who visited a Greek-speaking town and school in Calabria (Magna Grecia, southern Italy) in order to twin, got enthusiastic with their hosts' "extreme warmness" which reminded them of "the way Greeks used to behave 30 years ago": "These people were simple and poor but very open and hospitable." On the day of departure, the Italians offered Greeks huge boxes full of sandwiches and sweets to eat during their trip: "I was really moved ... they reminded me of what Greek villagers used to do for their visitors 30 years ago." The Italians' Greek was "poor" - "it sounded like Chinese" to the students - and the ancient monuments of that area were "humble and few", fewer than expected to be found in a former glorious colony of ancient Greeks! Such shortcomings were balanced, however, by the Italians' warmth: "Their warm and loving eyes made us also see these monuments in a different [more favourable] way." In short, southern Italians may be warmer than we Greeks, but they are lacking in something: they still live the way we lived 30 years ago! Or, to use Homi Bhabha's words, "they are almost the same [as us], but not quite": we are 30 years ahead! $!^{34}$ Greek twinners did not perceive southern Italians as "coeval", to recall Fabian's apt term; ${ }^{35}$ in their discourse of affection, warmness and coldness have an age status: the "warm, yet poor" Italians, Turks and Serbians remind them of "Greece back in the "60s", whereas the "coldness" of the French, Germans, and Dutch mirrors the equally passionless behaviour contemporary Greeks have now adopted, "but not quite". "Unlike them, we maintain some elements of our humane nature; we still feel and care for our fellow human beings." In cases where Greek twinners feel "30 years ahead", their "humane" character may take the form of a passionate "mission'. If the support promised materialises, the twinning between Greek missionaries and the Other may last long at least out of gratitude; if not, it may be postponed or never completed. Some Greeks who failed to prove that they are 30 years ahead of the Other have learned an unexpected lesson, namely that the Other is not external but rather internal to their own affective histories and economies of belonging. When the Greek mayor realised that his municipality could not afford all the goods he had promised to his "poor" Bulgarian twin partners, he refrained from offending them (for being poor) and defending himself (for being better off): "No matter how we wish to differ from Albanian immigrants, we are still Balkan." The unpleasant discovery that both Greeks and Bulgarians are equally deprived of the necessary means to fully prove their 'Europeanness' reminded him of the 'poor' aspects of Greek society that have been consciously forgotten over the last 20 years - the period when Greeks, these ex-migrants, became the nouveau-riche, European masters of Albanian, Polish and Bulgarian migrants within their own home.

\section{Europe for Citizens ss. Europe of Citizens}

All of the above-mentioned ethnographic vignettes show that the relations between twin partners tend to be ephemeral, ambiguous and unstable. For the EU, 'cultural differences' mean versions of the Same - the metaphoric use of "twinning" fits perfectly with the Union's master slogan of "Diversity in Unity". For the twin partners, however, cultural differences may denote the unexpected self-awareness vis-à-vis the Other, capable of leaving the twinning process in suspension; or the stirring of enough 'old wounds' to keep twinning in perpetual postponement; or the thermometric classification of partners into worthy and unworthy of one's own intimate feelings. 
In short, regardless of how connective (and disciplinary) the Union's éducation du coeur aims to be, twin brothers take the liberty to make their own culturally informed, emotional judgments of euro-symbols, thus 'adding' their own histories to the history of Europe, and consequently revealing Europe's chronic state of incompleteness.

This is exactly the reason why Commission officials have recently changed their policy concerning twinnings: they launched a new six-year project (2007-2013) entitled "Europe for Citizens" (instead of the previous "Europe of Citizens"), which includes civil, nongovernmental organisations in its budget. ${ }^{36}$ Feeling vulnerable after the unforeseen reactions of member states - such as the French and Dutch vote against the proposed European Constitution - and willing to remind Europeans of its monopoly to the "vertical topography of power", ${ }^{37}$ the Commission not only readopted a state-like paternalistic spirit ("Europe for Citizens") but had had recourse to that part of society (NGOs) which plays the role "of an imagined middle zone of contact or mediation between the citizen, the family and the community, on the one hand, and the state, on the other". 38 The keyword in this new protectionist program is "sustainability", followed by "coherence": from now on, applicants for funding must convince the Commission that their "synergies" will be both "socially repaying" and "lasting". The means suggested for the fulfilment of these goals are the "reflection", "debate" and "dialogue" on the part of European citizens about issues concerning the Union's repercussions on the "national-local level", and about "common projects widely applicable on the European level". Thematic conferences and seminars sponsored by at least three cities and organised by experts are the main requirements for financial support. In this new project, which privileges large-scale programmatic reflection and dialogue, the small-scale festivities accompanying twinnings are less preferred. The officials of the Council of European Municipalities and Regions have publicly opposed the new program by arguing that the "small" (implying the 'familial', the 'unofficial', the 'intimate'), and the "translocal" character of twinning constitute "the most powerful and fundamental elements towards the European integration". ${ }^{39}$

At first sight, the European Family Fathers (successors of the European Community Founding Fathers) seem to believe that "sustainability" can be better achieved through the faculties of reason and deliberation than through the politics of emotion and affection. Should we assume that, from now on, the Commission will make a distinction between the 'heart' and the 'mind' and will abandon the former as more unruly than the latter? I would suggest that the Commission's 'expertise' in matters European should not be underestimated: it seems to know well that so-called 'emotions' or 'feelings' (of affection/hostility) and 'sentiments' are not universal biological endowments, but culturally informed judgments of the regulatory ideals people are asked to perform in their everyday lives..$^{40}$ Consequently, they know that 'reflection' and 'dialogue' (commonly considered to belong to the separate sphere of 'mind' and 'reason'), as much as 'emotions' and 'sentiments' (usually seen as belonging to the sphere of the 'heart' and the 'body'), are but judgments of value that may question more than reaffirm the 'merely symbolic' solidities which are constructed by the Commissioners themselves in an effort to produce a - still elusive - "European public", and to endow the Union's emerging discourses and systems of transnational governmentality with - a still missing - "legitimacy". ${ }^{41}$ In the case of the new program, then, it is not a matter of privileging either reflection or emotion but of imposing new correlations of power: contrary to the thousands cities, towns and schools that twin with each other across the Union's territory, civil society or- 
ganisations are expected to be more 'collaborative' with the Commission, thus more controllable. Furthermore, contrary to the joyful celebrations performed in twinned cities, towns and villages all over Europe, conferences and expert seminars taking place in hotel function rooms of European cities are more accessible to 'EU representatives', hence closer to the Commission's surveillance. In short, the Europeans' éducation du coeur is subjected to more control. The change of the project's title from "Europe of Citizens" to "Europe for Citizens" is not 'merely symbolic', and hence of minor political and sentimental significance. In order to be financially supported, potential twin brothers and sisters must convince the Commission that their new synergies will be "sustainable" and "socially repaying", and that they will contribute to the European family's "coherence". Now, they are called upon to declare their loyalty to the European Family and its Founding Fathers through the implementation of long-lasting and stable, rather than ephemeral, ambiguous and unstable, twinning relations. In fact, they are imperatively asked to conform to an ideal emotional bond which was already there but hidden, and which Julia Kristeva, criticising all sorts of "brotherhoods", has so aptly phrased that "in order to have brothers, there must be a father".42

The extent to which future twin brothers and sisters will adapt their judgments to the new educational system of the heart, that is, whether they will prefer the reflection-oriented and surveyed grand synergies to the small-scale, locally performed festivities, is an interesting question. The list of the already approved "Conferences and Seminars of Citizens" shows that the European Family's children who conformed the most to the paternalistic character of the new project are the so-called "new members", especially the ones that killed their Father and looked for a better One.

\section{NOTES}

Acknowledgments: I would like to thank the organisers of the conference for having invited me to present an earlier version of this paper. My special thanks go to my friend and colleague Athena Athanasiou for her insightful comments on my first draft. She bears no responsibility for the final result.

1 For the whole range of these cultural policies introduced by the European Commission, see Cris Shore, Building Europe: The Cultural Politics of European Integration, London and New York: Routledge, 2000, pp. 46-50 and passim. The book analyses the role of the terms "culture" and "cultural" in the EU's integration project, especially from the mid-1970s, to the present day.

2 For the whole range of these "symbolic measures" introduced by the European Commission, see Shore, Building Europe, pp. 46-50 and passim.

3 Cited in Pascal Fontaine, A Citizen's Europe, Luxembourg: OOPEC, 1993, p. 7.

4 Shore, Building Europe, p. 229.

5 Fontaine, A Citizen's Europe, pp. 7-8.

6 Yannis Stavrakakis, "Passions of Identification: Discourse, Enjoyment, and European Identity”, in David Howarth and Jacob Torfing (eds), Discourse Theory in European Politics: Identity, Policy and Governance, Basingstoke: Palgrave Macmillan, 2004, p. 82. 
7 Mark Leonard, Europe: The Search for European Identity, London: Demos, 1998, p. 7.

8 Shore, Building Europe.

9 Stavrakakis, "Passions of Identification".

10 Shore, Building Europe, p. 229.

11 Catherine A. Lutz and Lila Abu-Lughod, "Introduction: Emotion, Discourse, and the Politics of Discourse", in Catherine A. Lutz and Lila Abu-Lughod (eds), Language and the Politics of Emotion, Cambridge: Cambridge UP, 1990, p. 1 and passim.

12 Ann Laura Stoler, Carnal Knowledge and Imperial Power: Race and the Intimate in Colonial Rule, Berkeley/ London: University of California Press, 2002, p. 129.

13 On the EU politics of European monetary union, see Shore, Building Europe, pp. 87-142.

14 Perhaps it is worth adding to this example the indignation Greeks feel when they are obliged to "change currency" when they travel to the UK and, conversely, the pleasure or relief (or even pride?) felt when they are heading to Italy, France or Slovenia.

15 Stoler, Carnal Knowledge, p. 10.

16 From Valéry Giscard d'Estaing's speech to the 8th Congress of European Twinned Towns: "Beyond Exchange", 22-24 May 2002, Belgium.

17 In Greece, twinning translates as adelphopoesis, which stems from the words adelphos (brother) and poesis (making of). Its male character is due to ceremonies between male family or clan representatives, since ancient times, in order to prevent mutual feelings of hostility or to amend murderous acts of fighting. Partners would cut their veins and mix their blood in order to ensure the immutable nature of their fictive kin ties.

18 On the politics of reconciliation in the form of brotherhoods in ancient Athens and in Sicily, see Nicole Loraux, The Divided City: On Memory and Forgetting in Ancient Athens, transl. Corinne Pache with Jeff Fort, New York: Zone Books, 2006.

19 Veena Das, Life and Words: Violence and the Descent into the Ordinary, Berkeley/London: University of California Press, p. 33.

20 Stoler, Carnal Knowledge, p. 18 and passim; see also Elizabeth A. Povinelli, The Empire of Love: Toward a Theory of Intimacy, Genealogy, and Carnality, Durham and London: Duke UP, 2006.

21 Benedict Anderson, Imagined Communities Reflections on the Origin and Spread of Nationalism, rev. ed., London and New York: Verso, 1983.

22 Das, Life and Words, p. 6 and passim.

23 Paul Ricoeur, "Reflections on a New Ethos for Europe", in Richard Kearney (ed.), Paul Ricoeur: The Hermeneutics of Action, London: Sage, 1996, p. 11.

24 Shore, Building Europe, p. 83, emphasis added.

25 Povinelli, Empire of Love, p. 192 and passim.

26 Hannah Arendt, The Human Condition, Chicago: University of Chicago Press, 1958, p. 28, cited in Povinelli, Empire of Love, p. 195. 
27 Povinelli, Empire of Love, p. 195.

28 On this issue, see, for example, Anthony Giddens, The Transformation of Intimacy: Sexuality, Love and Eroticism in Modern Societies, Stanford: Stanford UP; Bryan S. Turner, "Love as Risk: Outline of a Sociology of Love", in Ann Kristin Carlstrom, Lena Gerholm and Ingrid Ramberg (eds), Embodying Culture: Perpectives on Transformations of Gender, Health and Sexuality in the Complex Society, Botkyrka: Multicultural Centre, 2000, pp. 15-45; Don Kulick, "What Is This Thing Called Love?", in Carlstrom et al. (eds), Embodying Culture, pp. 46-52.

29 Povinelli, Empire of Love, p. 187.

30 For the differences and similarities between hetairos, the Greek word for partner, and "brother" in ancient Greece, see Loraux, The Divided City, p. 207.

31 Other transliterations include any combination of the words Palaia/Palea/Palia and Fokaia/Fokea/ Phocea/Phocaea.

32 Foceans (or Fokaeis) belong to those Greek-speaking Orthodox Christians who lived along the Asia Minor coast for centuries (long before the Ottoman Empire was established), and who were violently dislocated at the end of the Greco-Turkish War (1922). For an elaborate analysis of the specific twinning, see Eleni Papagaroufali, "Town Twinning in Greece: Reconstructing Local Histories through Translocal Sensory-Affective Performances", History and Anthropology 16:3 (2005), pp. 335-347.

33 For the notion of "witnessing" as a means of acknowledging the political history of the Other, see Nadia C. Seremetakis, The Last Word: Women, Death and Divination in Inner Mani, Chicago: University of Chicago Press, 1994; on the topic of "acknowledgment", see Das, Life and Words.

34 Homi K. Bhabha, The Location of Culture, London and New York: Routledge, 1994, p. 86 and passim.

35 Johanes Fabian, Time and the Other: How Anthropology Makes Its Object, New York: Columbia UP, pp. 30-31 and passim.

36 All of the following information related to the new program is available at: $h$ ttp://ec.europa.eu/citizenship/ guide_en.html (accessed 1 July 2008).

37 James Ferguson and Akhil Gupta, “Spatializing States: Toward an Ethnography of Neoliberal Governmentality", American Ethnologist 29:4 (2002), p. 995.

38 Ibid., p. 983.

39 From Jeremy Smith's (Secretary-General of the CEMR) speech, given at the Europe for Citizens Forum, Brussels, 28-29 September 2006.

40 Lutz and Abu-Lughod, "Introduction: Emotion, Discourse”. See also, Sara Ahmed, The Cultural Politics of Emotion, New York and London: Routledge, 2005; Maruska Svasek, "Introduction: Emotions in Anthropology", in Kay Milton and Maruska Svasek (eds), Mixed Emotions: Studies of Feeling, New York: Berg, 2005; Martha Nussbaum, "Emotions as Judgments of Value: A Philosophical Dialogue", Comparative Criticism 20 (1998), pp. 33-62.

41 Shore, Building Europe, pp. 3-4.

42 Julia Kristeva, Strangers to Ourselves, transl. Leon S. Roudiez, New York: Columbia UP, 1991, p. 192. 